\title{
STRATEGI PENDIDIKAN AGAMA ISLAM PADA PEMBELAJARAN AKIDAH "PENCEGAHAN DAN PENANGGULANGAN PENYEBARAN ALIRAN SESAT"
}

\author{
Mia Fitriah Elkarimah \\ Program Studi Bahasa Inggris, Universitas Indraprasa PGRI Jakarta \\ Email: El.karmah@gmail.com
}

\begin{abstract}
Abstrak
Penelitian ini bertujuan menggambarkan strategi pendidikan Agama Islam pada pembelajaran akidah di lembaga pendidikan formal terutama disekolah umum upaya mencegah dan menanggulangi penyebaran aliran sesat di Smk Teratai Putih Global 4 Bekasi. Dengan permasalah pelajaran Agama di sekolah umum cukup minim yaitu 2 jam perminggu, sedangkan pembahasan tentang akidah tersebut amatlah penting. Penelitian ini menggunakan teknik studi kasus karena termasuk penelitian kualitatif. Data diperoleh dengan wawancara, analisis dokumentasi, dan pengamatan partisipatif. Dalam penelitian ini, penulis menggunakan jenis data kualitatif yang menyangkut data-data tentang masalah-masalah yang akan dibahas, yakni strategi pencegahan dan penanggulangan aliran sesat dan menyesatkan. Adapun teknik pengumpulan data dilakukan dengan cara observasi, wawancara, studi dokumentasi dan triangulasi. Hasil penelitian menunjukkan bahwa strategi PAI pada pembelajaran akidah secara umum meliputi: 1) Menyelipkan materi akidah yang terkait dengan pencegahan aliran sesat melalui mapel PAI di asistensi perdana (pendahuluan) atau sebelum pemberian materi. Substansinya adalah memberikan informasi atau pemahaman terkait adanya gerakan (harakah) aliran-aliran yang sesat dan menyesatkan, kemudian disampaikan pula perihal kriterianya, strategi perekrutannya, bahayanya, dan tips agar terhindar dari ajakannya. 2), pengajian akidah rutinan selama 5 menit setelah shalat dzuhur bejamaah. 3) Pembinaan akidah pada organisasi keagamaan siswa (rohis).
\end{abstract}

Kata Kunci: Strategi Pendidikan Agama Islam, Pembelajran Akidah, Aliran Sesat, SMK Teratai Putih Global 4 Bekasi.

\begin{abstract}
This research aims to describe the strategy of Islamic Education (PAI) on learning of aqidah in formal educational institutions, especially in public school in an effort to prevent and overcome a heresy in SMK Teratai Putih Global 4 Bekasi. The problem of learning aqidah in Islamic education in public school is the lack of time which is only 2 hours a week. This qualitative research uses a case study technique, in which the data are acquired through an interview, document analysis, participatory observation and triangulation techniques. In this research, the researcher uses qualitative data related to issues to be discussed, namely the strategy of preventing and overcoming a heresy. The result of the research shows that in general, strategy of Islamic education on aqidah learning includes: 1) Incorporating aqidah materials on heresy prevention through Islamic Education subject in initial assistance (introduction) or before teaching the materials. The substance is providing information or understanding related to a heretical movement (haraqah), then explaining its criteria, recruitment strategies, dangers and tips to avoid its persuasion. 2), learning aqidah routinely for 5 minutes after performing dzuhur prayer together, 3) providing aqidah mentoring to student's Islamic organization (rohis).
\end{abstract}

Keywords: Strategy of Islamic Education, Learning of Aqidah, Heresy, SMK Teratai

Putih Global 4 Bekasi.

\section{Pendahuluan}

Pendidikan identik dengan perkembangan manusia itu sendiri "Life is education, and education is life" (Murni Jamal (dalam Desi Oktarianti), 2014:108). Pemahaman seperti itu 
tidak jauh dengan pandangan Islam. Sejak awal kelahirannya, Islam sudah memberikan penghargaan yang besar kepada ilmu. Ketika Rasulullah SAW menerima wahyu pertama, yang mula-mula diperintahkan kepadanya adalah "membaca", hal tersebut mengindikasikan betapa urgent nya kegiatan membaca bagi umat manusia. Membaca merupakan Salah satu pembelajaran yang mengaplikasikan nilai-nilai pendidikan.

Menurut Jalaluddin (2010:108), pendidikan adalah bagian dari kebutuhan manusia. Manusia membutuhkan pendidikan, dalam kaitan dengan pengembangan potensi yang dimilikinya. Demikian pentingnya fungsi dan peran pendidikan ini, sampai-sampai Islam menempatkan pendidikan sebagai bagian dari kewajiban agama.Pendidikan berasal dari kata dasar "didik" yang mengandung arti pelihara dan latih (KKBI, 2005: 263). Konsep pendidikan dalam bentuk praktik mengarah pada pengertian pendidikan sebagai suatu "proses". Secara sederhana berarti proses usaha manusia untuk membina kepribadian . Pada dasarnya pendidikan adalah laksana ekperimen yang tidak akan pernah selesai sampai kapanpun, sepanjang ada kehidupan manusia di dunia.

Dilihat dari segi hakikat pendidikan, ternyata kegiatan mendidik memang merupakan bagian yang tak terpisahkan dari kehidupan agama, maka muncullah konsep pendidikan Islam, Perbedaan pendidikan dan pendidikan islam tidak jauh berbeda karena tujuan pendidikan itu tidak bisa lepas dari tujuan hidup manusia, jika pada pendidikan Islam adalah pendidikan yang seluruh aspek atau komponenya didasarkan pada ajaran Islam. Sedangkan pendidikan secara umum tidak semua didasarkan pada ajaran islam.

Tantangan yang dihadapi dalam Pendidikan Agama, khususnya Pendidikan Agama Islam sebagai sebuah mata pelajaran adalah bagaimana mengimplementasikan pendidikan agama Islam bukan hanya mengajarkan pengetahuan tentang agama akan tetapi bagaimana mengarahkan peserta didik agar memiliki kualitas iman, taqwa dan akhlak mulia. Dengan demikian materi pendidikan agama bukan hanya mengajarkan pengetahuan tentang agama akan tetapi bagaimana membentuk kepribadian siswa agar memiliki keimanan dan ketakwaan yang kuat dan kehidupannya senantiasa dihiasi dengan akhlak yang mulia dimanapun mereka berada, dan dalam posisi apapun mereka bekerja.

Aspek akidah merupakan domain utama dalam kurikulum Pendidikan agama Islam (PAI). Secara etimologis, akidah berarti ikatan, sangkutan, atau janji. (Lois Ma'luf, tt: 518-519). Secara terminologi, akidah berarti kepercayaan yang dianut oleh orang-orang yang beragama atau tali yang mengokohkan hubungan manusia dan tuhan. Menurut W. Montgomery Watt sebagaimana dikutip oleh Asep Usman Ismail, akidah sebagai salah satu istilah dalam Islam, mengalami perkembangan dalam penggunaannya. Pada permulaan Islam, akidah belum digunakan untuk menyebut pokok kepercayaan Islam yang bersumber dari syahadat atau kesaksian bahwa tidak ada tuhan selain Allah. Istilah akidah baru disebut-sebut dalam diskusi para ulama ilmu kalam. Puncak perkembangannya, istilah akidah dipergunakan untuk menunjuk keyakinan dasar dalam Islam yang komprehensif (2012: 4).

\section{Tinjauan Pustaka}

Akidah itu mempunyai sifat keyakinan dan kepastian sehingga tidak mungkin ada peluang bagi seseorang untuk meragukannya. Dengan demikian, akidah merupakan sistem keyakinan Islam yang mendasari seluruh aktivitas umat Islam dalam kehidupannya. Akidah atau sistem keyakinan Islam dibangun atas dasar enam keyakinan atau yang biasa disebut dengan rukun iman yang enam.

Dilihat dari sejarah, Nabi berdakwah di Mekah lebih lama selama 13 tahun, sedangkan di Madinah, Nabi berdakwah 10 tahun saja (Nasir ibnu Abdil Karim: 24). Menurut Abudinnata (2011: 81), kurikulum pendidikan di Mekah berisi materi pengajaran yang berkaitan dengan 
akidah. Disinilah Islam menegaskan akan pentingnya akidah bagi seorang Muslim, Akidah harus terpatri kuat dan menjadi motivator utama bagi umatnya. Itulah sebabnya kenapa Rasulullah SAW mengawali dakwahnya pada akidah, karena ia fondasi, di mana seluruh komponen ajaran Islam tegak di atasnya. Dan ia juga berfungsi sebagai ruh, tanpa akidah maka syari'at tidak ada gunanya.

Dari paparan di atas penulis memformulasikannya namun pada hakekatnya yang membuat rumusan itu mempunyai titik tekan yang sama tentang apa pendidikan akidah itu sendiri. Bahwa pendidikan akidah merupakan suatu sarana pendidikan agama Islam yang didalamnya terdapat bimbingan dari pendidik kepada peserta didik agar mereka mampu memahami, menghayati, dan meyakini kebenaran ajaran agama Islam, serta menjadikan akidah Islam itu sebagai suatu pandangan hidupnya dalam berbagai kehidupan.

Banyaknya kaum muda yang menjadi sasaran sebagai penganut aliran-aliran baru tersebut mengindikasikan bahwa lemahnya akidah islam. Terbukti mayoritas adalah mahasiswa dan pelajar yang terjebak dalam pembaharuan agama dengan kurangnya pondasi dan pemahaman yang kokoh terhadap akidah islam. Oleh karena itu apakah peran pendidikan akidah (Islam) di sekolah-sekolah masih kurang. Padahal banyak munculnya lembaga-lembaga pendidikan yang berbasis Islam, yang seharusnya mampu menyiapkan kaum muda muslim yang tahan akan deras globalisasi dan tetap mempertahankan akidahnya.

Kasus penyebaran aliran sesat dan menyesatkan telah berlangsung sejak lama. Penyebaran aliran sesat ini terjadi bukan hanya di kalangan masyarakat umum, namun terjadi pula di berbagai institusi terutama institusi pendidikan, baik tingkat menengah maupun perguruan tinggi. Di tingkat menengah, penyebaran aliran sesat ini sebagaimana sering diberitakan oleh bermacam media cukup gencar; ditandai dengan terungkapnya beberapa kasus korban aliran sesat banyak yang berstatus sebagai pelajar. Dari kasus yang terjadi di atas, penyebaran aliran atau paham yang sesat dan menyesatkan berikut modusnya jika dibiarkan jelas-jelas akan mengancam keselamatan generasi umat Islam saat ini dan yang akan datang. Ditinjau dari aspek bahayanya, aliran-aliran dan paham yang sesat dan menyesatkan tersebut memiliki dampak yang cukup kompleks, antara lain menimbulkan keresahan bagi masyarakat muslim secara luas, karena banyak orang tua yang merasa tertipu dengan sikap anaknya bahkan kehilangan anggota keluarganya. korban pengikut aliran ini juga berani meninggalkan tempat belajarnya dan berani melakukan apa saja untuk mendapatkan materi demi membayar infak yang telah ditentukan, meskipun dengan cara menipu orang tuanya sendiri. Lebih parah lagi, mereka terjebak dalam kekeliruan dalam memahami ajaran Islam yang sering menimbulkan sikap meresahkan masyarakat khususnya umat Islam seperti shalat belum diwajibkan, dosa dapat dihapus dengan penyerahan uang, dan lain sebagainya.

Dengan latar belakang inilah peneliti akan memaparkan strategi pembelajaran akidah pada mata pelajaran agama Islam dengan kendala kurangnya waktu yang disediakan dalam menyampaikan materi akidah di mapel pai . karena pemerintah hanya menentukan dua jam mata pelajaran dan hanya sekali dalam seminggu.

\section{Metodologi Penelitian}

Penelitian ini menggunakan pendekatan deskriptif kualitatif, maka kehadiran peneliti di lapangan sangat penting. Peneliti bertindak langsung sebagai instrument dan sebagai pengumpul data hasil observasi yang mendalam serta terlibat aktif dalam penelitian. Data yang berbentuk kata-kata diperoleh dari para informan, sedangkan data tambahan berupa dokumen. Analisa data dilakukan dengan cara menelaah data yang ada, lalu melakukan reduksi data, penyajian data dan menarik kesimpulan dan tahap akhir dari analisa data ini mengadakan keabsahan data dengan menggunakan ketekunan pengamatan triangulasi. Sebelum penelitian dilaksanakan, maka perlu ditentukan sumber data yaitu subjek dari mana 
data diperoleh, sehingga peneliti memperoleh sumber data yang dipandang paling mengetahui dan berhubungan langsung dengan masalah yang diteliti. Responden adalah orang yang merespon atau menjawab pertanyaan-pertanyaan peneliti baik pertanyaan tertulis maupun lisan (Arikunto, 2010:107). Sedangkan informan adalah orang yang menjadi sumber data dalam penelitian (Alwi, 2007:794). Adapun yang menjadi responden atau informan dalam penelitian ini adalah Guru Pendidikan Agama Islam di SMK Teratai Putih Global 4

\section{Hasil dan Pembahasan}

Jika kita cermati pada keadaan sekarang ini Pendidikan Agama Islam (PAI) di sekolah atau di madrasah, dalam pelaksanaannya masih menunjukkan berbagai permasahalan yang kurang menyenangkan. Seperti halnya proses pembelajaran Pendidikan Agama Islam (PAI) di sekolah saat ini masih sebatas sebagai proses penyampaian "pengetahuan tentang Agama Islam". Tidak hanya itu, semakin tingginya tingkat pindahnya akidah para peserta didik menjadi bukti bahwa pembelajaran Pendidikan Agama Islam, terutama pembelajaran Akidah yang menyangkut pembentukan keyakinan Islam peserta didik hanya terjadi sebatas transfer ilmu atau bisa dikatakan pembelajarannya berorientasi pada penyampaian tentang konsepkonsep akidah Agama Islam saja. Belum menyentuh pada internalisasi nilai-nilai Agama yang ada di dalamnya ke dalam jiwa peserta didik.

Pada akhir-akhir ini dinamika umat Islam di Indonesia diramaitkan dengan berkembangnya berbagai komunitas religius yang mengembangkan seperangkat ajaran yang berbeda dengan ajaran Islam yang telah dipraktikkan oleh umat Islam selama ini. Berbagai pernyataan pemuka agama dan institusi keagamaan yang muncul sebagai respon terhadap komunitas tersebut, hingga lahirnya pernyataan sikap yang mencap aliran-aliran keagamaan atau komunitas religius tersebut sebagai aliran sesat atau komunitas sesat.

Apabila dirunut ke belakang, jauh sebelumnya sudah sejumlah aliran keagamaan sempalan di Indonesia, yang mungkin karena struktur masyarakat muslim Indonesia yang heterogen dan sikap akomodatif masyarakat muslim menyebabkan aliran-aliran keagamaan sempalan tersebut mudah diterima hingga tumbuh subur dan berkembang ditambah lagi dengan kurangnya efektifnya pelajaran agama Islam khususnya aspek pengajran akidah ditingkat sekolah.

Kurang efektifnya pelajaran agama Islam dilihat dari pembagian waktunya, bila kita melihat perbandingan antara banyaknya waktu pembelajaran mapel agama atau pendidikan agama Islam antara sekolah umum dengan madrasah akan sangat berbeda jauh. Sekolah umum hanya memiliki dua jam mapel PAI sekali dalam seminggu. Sedangkan di madrasah mapel PAI masih dipecah menjadi lima mapel yaitu aqidah akhlak, fiqih, sejarah kebudayaan Islam, qur'an hadits dan bahasa arab. Sehingga tiap-tiap mapel pai tersebut juga mendapatkan jam masing-masing dalam setiap pertemuannya dalam seminggu.

Hal ini tidak sebanding dengan jumlah jam pada mata pelajaran yang lain. Apalagi jika dibandingkan dengan mata pelajaran yang masuk dalam ujian nasional. Pendidikan agama Islam adalah pelajaran yang paling penting dan pelajaran yang sangat diperlukan. Hal ini dilihat berdasarkan dari kacamata agama Islam. Mengingat bahwa mayoritas masyarakat Indonesia adalah beragama Islam. Mata pelajaran ini harus mendapatkan perhatian lebih dari berbagai pihak.

TAP MPRS nomor XXVII/MPRS/1966 Bab I Pasal I yang berbunyi: "Menetapkan pendidikan agama menjadi mata pelajaran di sekolah-sekolah mulai dari Sekolah Dasar sampai dengan Universitas-Universitas Negeri”. Peraturan ini keluar dengan tanpa protes, setelah penumpasan PKI (Muhammad Kholid Fathoni, 2005:37). 
Dengan makin kuatnya posisi Pendidikan Agama Islam di dalam sistem pendidikan Indonesia dengan lahirnya UU nomor 20 tahun 2003 tentang Sistem Pendidikan Nasional yang lebih menjamin pemenuhan pendidikan agama kepada peserta didik. Dan diikuti dengan lahirnya peraturan-peraturan selanjutnya sampai dengan terbitnya Peraturan Menteri Agama RI Nomor 16 Tahun 2010 tentang Pengelolaan Pendidikan Agama Pada Sekolah.

Ruang lingkup Pendidikan Agama Islam ditingkat sekolah, semua berkaitan dengan keserasian, keselarasan, dan keseimbangan antara hubungan manusia dengan Allah SWT, hubungan manusia dengan sesama manusia, dan ketiga hubungan manusia dengan dirinya sendiri, serta hubungan manusia dengan makhluk lain dan lingkungannya. Apabila dilihat dari segi pembahasannya maka ruang lingkup Pendidikan Agama Islam yang umum dilaksanakan di sekolah adalah (a) Ilmu Tauhid / Keimanan, (b) Ilmu Fiqih, (c) Al-Qur"ean, (d) Al-Hadist, (e) Akhlak dan (f) Tarikh Islam (Zuhairini dan Abdul Ghafir, 2004: 48).

Dan apabila dijabarkan adalah sebagai berikut: Pengajaran Al-Quran, Pertama; Pengajaran Al-Quran adalah pengajaran yang bertujuan agar siswa dapat membaca Al-Quran dan mengerti arti kandungan yang terdapat di setiap ayat-ayat Al-Quran. Akan tetapi dalam prakteknya hanya ayat-ayat tertentu yang di masukkan dalam materi Pendidikan Agama Islam yang disesuaikan dengan tingkat pendidikannya. Kedua; pengajaran Al-Hadits adalah pengajaran yang bertujuan agar siswa dapat membaca Al-Hadits dan mengerti arti kandungan yang terdapat di dalam Al-Hadits. Akan tetapi dalam prakteknya hanya haditshadits tertentu yang di masukkan dalam materi Pendidikan Agama Islam yang disesuaikan dengan tingkat pendidikannya. Ketiga; Pengajaran keimanan (Akidah). Pengajaran keimanan berarti proses belajar mengajar tentang aspek kepercayaan, dalam hal ini tentunya kepercayaan menurut ajaran Islam, inti dari pengajaran ini adalah tentang rukun iman. Keempat pengajaran akhlak dengan tujuan supaya yang diajarkan berakhlak baik. Kelima; Pengajaran fiqih yang isinya tentang cara beribadah dan terakhir sejarah dan Kebudayaan Islam, tujuan pengajaran dari sejarah Islam ini adalah agar siswa dapat mengetahui tentang pertumbuhan dan perkembangan agama Islam dari awalnya sampai zaman sekarang sehingga siswa dapat mengenal dan mencintai agama Islam.

Dalam pengajaran akidah pada PAI dapat diartikan sebagai pengajaran iman atau keyakinan. Kedudukannnya menjadi sangat fundamental karena iman atau tauhid menjadi inti dari segala aspek. Adapun nilai-nilai yang tergambar dalam pengajaran akidah ini adalah rukun iman, yaitu:1). Iman kepada Allah. 2). Iman kepada Malaikat-malaikat Allah. 3). Iman kepada kitab-kitab Allah. 4). Iman kepada Rasul Allah. 5). Iman kepada hari Akhir. 6). Iman kepada qada' dan qadar (Mohammad Daud, 2011: 201)

Terdapat beberapa aspek dalam pembelajaran pendidikan agama Islam, ada aspek kognitif, aspek afektif, aspek psikomotorik. Aspek kognitif menyangkut pengetahuan akan keyakinan. Aspek afektif menyangkut tentang tabiat, sikap atau perasaan. Sedang aspek psikomotorik menyangkut perilaku siswa/i. Aspek-aspek ini saling mempengaruhi dan melengkapi satu sama lainnya. Maka dari itu diharapkan kita dapat menyeimbangkannya. Aspek yang paling penting dan mengawali seluruh aspek yang ada yaitu aspek kognitif. Aspek ini adalah aspek dasar yang dalam ajaran agama Islam disebut juga aspek akidah. Akidah berarti kepercayaan atau keyakinan yang benar-benar melekat di hati manusia. Aspek kognitif akan mempengaruhi perkembangan dua aspek lainnya . Baik aspek afektif atau bisa disebut aspek akhlak dan aspek psikomotorik atau bisa disebut aspek ibadah. Jika seorang anak itu tahu mana hal yang baik dan mana hal yang buruk, maka dia akan dapat mengatur atau mengontrol dirinya dalam setiap perbuatan yang akan dilakukannya. Maka dari itu pentingnya pendidikan ini harus memiliki dasar yang kuat, dan harus mendapatkan perhatian yang serius dari banyak pihak. Khususnya dari pihak orangtua, pendidik, pemerintah dan seluruh pihak yang terkait. 
Aliran sesat adalah sekelompok manusia atau organisasi yang terorganisir yang memiliki pemahaman atau aturan-aturan tertentu yang bertentangan dengan ajaran Islam; menyimpang dari Al-Qur'an dan Sunnah. Pengikut suatu aliran tertentu adalah orang-orang yang telah terdoktrin pikirannya, tidak suka dialog, serba dogmatis, antikritik, dan cenderung merasa paling benar (Hartono Ahmad Jaiz, 2010: ix). Majelis Ulama Indonesia dalam Rapat Kerja Nasional pada 25-26 Syawal 1428 H/ 5-6 November 2007 telah menetapkan kriteria aliranaliran dalam Islam yang sesat dan menyesatkan, antara lain: (Didin Hafidhuddin, 2007) Pertama, mengingkari rukun iman yang enam dan rukun Islam yang lima. Kedua, meyakini dan atau mengikuti akidah yang tidak sesuai dengan dalil syar'i (Al-Qur'an dan Sunnah), misalnya meyakini seseorang telah mendapatkan wahyu dari Malaikat Jibril, sebab wahyu sudah terputus dengan kerasulan Nabi Muhammad saw. Ketiga, meyakini turunnya wahyu setelah Al-Qur'an, padahal Al-Qur'an adalah wahyu atau kitab terakhir yang diturunkan kepada Rasulullah saw, merujuk pada firman Allah swt.: "Pada hari ini orang-orang kafir telah putus asa untuk (mengalahkan) agamamu, sebab itu janganlah kamu takut kepada mereka dan takutlah kepada-Ku. Pada hari ini telah Kusempurnakan untuk kamu agamamu, dan telah Ku-cukupkan kepadamu ni mat-Ku, dan telah Ku-ridhai Islam itu jadi agama bagimu..." (QS. Al-Maidah (3): 3).8. Keempat, mengingkari otentisitas dan atau keberadaan isi Al-Qur'an. Kelima, melakukan penafsiran Al-Qur'an yang tidak berdasarkan kaidah tafsir. Keenam, mengingkari kedudukan hadis Nabi sebagai sumber ajaran Islam. Ketujuh, melecehkan dan atau merendahkan para Nabi dan Rasul. Kedelapan, mengingkari Nabi Muhammad Saw sebagai Nabi dan Rasul terakhir. Kesembilan, mengubah pokok-pokok ibadah yang telah ditetapkan syari'at, seperti mengubah waktu shalat, praktik shalat, dan lain-lain. Kesepuluh, mengkafirkan sesama muslim tanpa dalil syar'i.

Dalam dunia pendidikan, strategi diartikan sebagai perencanaan yang berisi tentang rangkaian kegiatan yang didesain untuk mencapai tujuan pendidikan tertentu. Sedangkan Kemp (1995) menjelaskan bahwa strategi pembelajaran adalah suatu kegiatan pembelajaran yang harus dikerjakan guru dan siswa agar tujuan pembelajaran dapat dicapai secara efektif dan efisien. Dari pendapat tersebut, Dick and Carey (1985) juga menyebutkan bahwa strategi pembelajaran itu adalah suatu set materi dan prosedur pembelajaran yang digunakan secara bersama-sama untuk menimbulkan hasil belajar pada siswa (Abdul Majid, 2012 : 129).

Komponen dari strategi pembelajaran itu sendiri antara lain tujuan, bahan pelajaran, kegiatan belajar mengajar, metode, alat, sumber pelajaran dan evaluasi. Agar tujuan itu tercapai, semua komponen yang ada harus diorganisasikan sehingga antar sesama komponen terjadi kerjasama. Karena itu guru tidak boleh hanya memperhatikan komponen-komponen tertentu saja, tetapi harus mempertimbangkan komponen secara keseluruhan (Anisatul Mufarokah, 2009:43)

Subjek dalam penelitian ini 5 orang guru PAI yang terdiri dari 4 orang guru laki-laki dan 1 orang guru perempuan dan siswa siswi kelas XII SMK teratai putih global 4 bekasi, Dalam pembinaan akidah siswa-siswi, guru Pendidikan Agama Islam membutuhkan strategi dalam proses pembinaan tersebut. Walaupun dalam pelaksanaan pembinaan akidah siswa guru Pendidikan Agama Islam melibatkan komponen sekolah baik kepala sekolah, guru-guru lain serta aparat sekolah, dan juga melibatkan orang tua siswa, untuk sama-sama membimbing, mengawasi, mengarahkan anaknya saat dirumah.

Pada penelitian ini penulis dalam mengumpulkan data menggunakan sampel penelitian yaitu guru pendidikan agama islam. Berdasarkan hasil wawancara dengan guru pendidikan agama islam mereka sepakat bahwa permasalahan dalam PAI terutama yang berkenaan dengan proses pembelajaran, tidak lepas dari tiga sebab yang mendasar. Pertama, selama ini, banyak pendidikan agama yang lebih banyak berorientasi pada aspek kognitif saja. Padahal 
pendidikan agama seharusnya lebih berorientasi secara praktisi, maka tidak heran ketika banyak dijumpai anak yang menadapat nilai bagus dalam mata pelajaran agama akan tetapi dalam penerapan dan prilaku keseharian cenderung menyimpang dari norma ajaran yang islami. Dan eveluasi yang dilakukan untuk pendidikan agama disamakan dengan pelajaranpelajaran yang lain, yaitu hanya aspek kognitif saja. Pada hakikatnya evaluasi PAI idealnya tidak hanya dalam hal kognitif saja, akan tetapi lebih menekankan pada praktisi, supaya ajaran agama yang telah siswa pelajari bisa terlihat langsung dalam berprilaku sehari-hari (Muhaimin, 2009:158).

Kedua, sistem pendidikan agama yang berkembang di sekolah kurang sistematis dan kurang terpadu untuk anak didik.

\section{Tabel 1 Permasalahan Pendidikan Agama Islam}

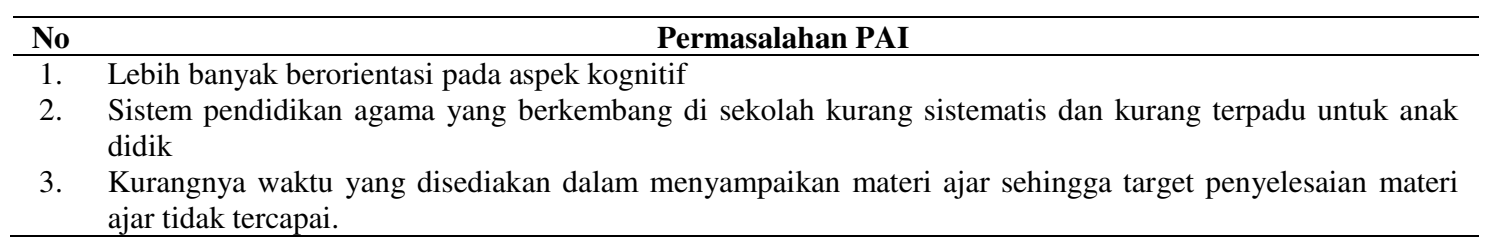

Problematika yang muncul pada mapel Pendidikan agama Islam adalah umumnya siswa yang telah belajar selama 12 tahun (SD, SMP, dan SMA), yang mana mata pelajaran agama hanya diajarkan dua jam saja dalam satu minggu, masih banyak yang belum bisa membaca Al-Qur'an dengan baik dan benar, tidak menjalankan kewajiban sholat secara rutin, dan yang paling penting hilangnya akidah dan banyaknya remaja yang masuk aliran keagamaan dilindonesia (Muhaimin, 2009:157)

Pendidikan agama Islam di sekolah umum mencakup keseluruhan materi di lima mapel PAI yang ada di madrasah. Seperti materi akidah, sejarah, tajwid atau hukum bacaan, hukum fiqih, akhlak . Kenyataannya guru pai juga mengalami kendala terhadap waktu yang telah ditentukan pemerintah yang hanya dua jam mata pelajaran dan hanya sekali dalam seminggu. Kendalanya ialah kurangnya waktu yang disediakan dalam menyampaikan materi ajar sehingga target penyelesaian materi ajar tidak tercapai.

Melihat kenyataan diatas, sebaiknya guru pai di SMK Teratai Putih Global 4 bersama kepala sekolah terkadang memberikan solusi dengan membuka dan mengadakan ekstrakurikuler untuk pembelajaran akidah, ini dimaksudkan untuk menjadi jam tambahan dari mapel PAI diluar KBM, agar siswa terbekali dari aspek religiusitas atau keagamaan yang cukup setelah ia lulus dari sekolah. Ada juga organisasi siswa yang diadakan untuk mendukung keagamaan siswa di sekolah yaitu ROHIS.

Memang tak bisa dipungkiri bahwa mata pelajaran PAI masih dikesampingkan oleh sekolah umum berbeda dengan madrasah yang notabenenya mengajarkan materi PAI dengan porsi yang cukup banyak. Untuk itulah, hal ini diharapkan menjadi perhatian yang sangat penting bagi pemerintah dalam mata pelajaran PAI agar para siswa di negara kita menjadi penerus bangsa yang beragama, bermoral dan berbudi pekerti yang luhur sesuai dengan cita-cita bangsa

Peserta didik dalam suatu lembaga pendidikan tentu berasal dari latar belakang kehidupan beragama yang berbeda-beda. Ada siswa yang berasal dari keluarga yang taat beragama, namun ada juga yang berasal dari keluarga yang kurang taat beragama, dan bahkan ada yang berasal dari keluarga yang tidak peduli dengan agama. Bagi anak didik yang berasal dari keluarga yang kurang taat atau tidak peduli terhadap agama, perlu perhatian yang serius. 
Sebab jika tidak, maka anak didik tidak akan peduli terhadap pendidikan agama, lebih parah lagi mereka menganggap remeh pendidikan agama. Sikap ini akan sangat berbahaya, meskipun demikian, tentu ada faktor-faktor yang mempengaruhi peserta didik seperti; minat belajar, keluarga, lingkungan, dan lain sebagainya.

Sedangkan aksi penyebar aliran sesat saat ini memang membuat masyarakat resah, namun sebagai antisipasinya yakni melalui peningkatan pendidikan agama yang benar kepada anak dan generasi muda Islam, salah satu upaya untuk mencegah pengaruh aliran sesat terhadap umat Islam adalah memperkuat pendidikan agama, terutama kepada anak-anak dan generasi muda. Memperkuat pendidikan agama misalnya dengan penambahan jam belajar agama di luar jam sekolah.

Dari kenyataan di atas strategi PAI pada pembelajaran akidah secara umum meliputi: 1). Menyelipkan materi akidah yang terkait dengan pencegahan aliran sesat melalui mapel PAI di asistensi perdana (pendahuluan) atau sebelum pemberian materi. Substansinya adalah memberikan informasi atau pemahaman terkait adanya gerakan (harakah) aliran-aliran yang sesat dan menyesatkan, kemudian disampaikan pula perihal kriterianya, strategi perekrutannya, bahayanya, dan tips agar terhindar dari ajakannya. 2), Pengajian akidah Islam yang benar rutinan selama 5 menit setelah shalat dzuhur berjamaah. Adapun jadwal pelaksanaanya biasanya dilaksanakan pada setiap hari rabu sehingga dikenal dengan istilah rabuan. Disamping itu, ada juga pengajian yang diselenggarakan oleh organisasi siswa (rohis) yang materinya terkadang terkait langsung dengan masalah gerakan aliran sesat. 3. Pengisian wejangan ketika upacara hari senin, ini diselenggarakan oleh TIM Pendidik Agama Islam minimal satu kali dalam satu bulan. Materi yang disampaikan pada stadium general ini pada dasarnya bersifat aktual (isu-isu kontemporer) diantaranya terkait dengan masalah eksistensi gerakan aliran sesat.4) Pembinaan akidah pada organisasi keagamaan siswa (rohis).

Tabel 2. Strategi Pembelajaran PAI Pada Pembelajaran Akidah

\begin{tabular}{|c|c|c|}
\hline No & & $\begin{array}{c}\text { Strategi PAI pada Pembelajaran Akidah } \\
\text { Di SMK Teratai Putih Global } 4 \\
\end{array}$ \\
\hline & $\mathrm{Kbm}$ & $\begin{array}{l}\text { 1. Menyelipkan materi akidah yang terkait dengan } \\
\text { pencegahan aliran sesat melalui mapel PAI di } \\
\text { asistensi perdana (pendahuluan) atau sebelum } \\
\text { pemberian materi }\end{array}$ \\
\hline & & $\begin{array}{l}\text { 2. Pengisian wejangan ketika upacara hari senin, ini } \\
\text { diselenggarakan oleh TIM Pendidik Agama Islam } \\
\text { minimal satu kali dalam satu bulan }\end{array}$ \\
\hline \multirow[t]{2}{*}{2.} & Diluar kbm & $\begin{array}{l}\text { 1. Pengajian akidah Islam yang benar rutinan } \\
\text { selama } 5 \text { menit setelah shalat dzuhur berjamaah. } \\
\text { Adapun jadwal pelaksanaanya biasanya } \\
\text { dilaksanakan pada setiap hari rabu sehingga } \\
\text { dikenal dengan istilah rabuan. }\end{array}$ \\
\hline & & $\begin{array}{l}\text { 2. Pembinaan akidah pada organisasi keagamaan } \\
\text { siswa (rohis) }\end{array}$ \\
\hline
\end{tabular}

\section{Simpulan dan Saran \\ Simpulan}

Dari uraian dan data-data, maka peneliti mengambil kesimpulan: 1. Keadaan siswa/i di SMK Teratai Putih Global 4 Bekasi pada umumnya sudah cukup baik, akan tetapi masih ada beberapa siswa yang masih harus dibina, dan dibimbing, perhatian dan kontrol yang ekstra dari para guru terutama guru PAI terkait dengan upaya pencegahan dan penanggulangan penyebaran aliran sesat. 2. Strategi Pendidikan Agama Islam di di SMK Teratai Putih Global 4 Bekasi mempunyai pengaruh besar terhadap siswa. 


\section{Saran}

Kegiatan pembelajaran akidah yang relatif dengan waktu yang singkat bisa disiasati dengan menambahkan diluar jam KBM, seperti pemberian materi akidah yang terkait dengan pencegahan aliran sesat melalui mapel PAI di asistensi perdana (pendahuluan) atau sebelum pemberian materi, pengajian akidah rutinan selama 5 menit setelah shalat dzuhur bejamaah. Optimalisasi pembinaan keagamaan pada organisasi keagamaan siswa (rohis) oleh tim PAI. Strategi diatas sangat membantu untuk tercapainya pembelajaran akidah pada mapel PAI.

\section{Daftar Pustaka}

Ali, Mohammad Daud. (2011). pendidikan agama islam, Jakarta:Raja Grafindo Jaya. Alwi, Hasan. (2007). Kamus Besar Bahasa Indonesia. Jakarta: Balai Pustaka

Arikunto, Suharsimi. (2010). Prosedur Penelitian Suatu Pendekatan Praktek. Jakarta: Rineka Cipta.

Didin Hafidhuddin. 2007. "Kriteria-Kriteria Aliran (Islam) yang Sesat dan Menyesatkan", Materi Kapita Selekta Kuliah Pendidikan Agama Islam Program Pendidikan Tingkat Persiapan Bersama (TPB-IPB), 2007

Fathurrohman, Pupuh \& M. Sobry Sutikno. Strategi Belajar Mengajar. Bandung :Refika Aditama

Hartono Ahmad Jaiz. (2010). Aliran dan Paham Sesat di Indonesia. Jakarta: Pustaka Al Kautsar.

Konsep Pendidikan Akidah Perspektif Islam (Studi Tafsir Tarbawi). (2014). Sekolah Tinggi Islam Baturaja, Indonesia. Vol 14, No 1

Muhaimin. (2009) Rekonstruksi Pendidikan Islam;Dari Paradigma Pengembangan, Manajemen, Kelembagaan, Kurikulum Hingga Strategi Pembelajaran. Jakarta: PT RajaGrafindo Persada.

Muhammad Kholid Fathoni. (2005), Pendidikan Islam dan Pendidikan Nasional (Paradigma baru), Jakarta:Direktorat Jenderal Kelembagaan Agama Islam Departemen Agama

Mulia, cet.4.

Ramayulis. (2005). Metodologi Pendidikan Agama Islam, (Jakarta : Kalam

Tim Penyusun Kamus Pusat Pembinaan Bahasa. (2005). Kamus Besar Bahasa Indonesia. Jakarta: Balai Pustaka

Zuhairini dan Abdul Ghafir. (2004). Metodologi Pendidikan Agama Islam. Malang: UM Press 